\section{Liten bok om prostatakreft}

Malcolm Mason, Leslie Moffat

Prostate cancer

2. utg. 120 s, tab, ill. Oxford: Oxford University Press, 2010. Pris GBP 10

ISBN 978-0-19-957393-6

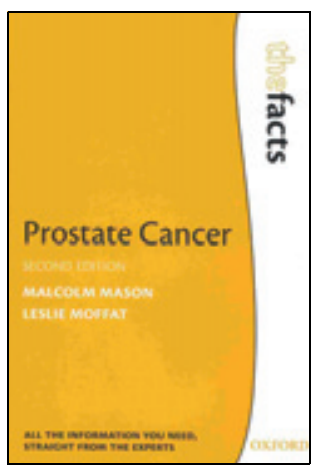

I denne lille boken henvender forfatterne seg forst og fremst til menn som vurderer en undersøkelse med henblikk på å utelukke eller diagnostisere prostatakreft, eller som nettopp har fått diagnosen. De diskuterer de nyeste funnene innen PSA.-screening og radikal behandling, som den europeiske screeningstudien. Både gevinsten (redusert mortalitet) og problemene (overdiagnose, bivirkninger) fremstilles. Her savner jeg en kort omtale av den amerikanske screeningstudien. De aksepterte metodene for kurativ behandling av prostatakreft (prostatektomi, strålebehandling) blir omtalt. Høyintensitetsfokusert ultralyd (HIFU)-behandling og kryobehandling nevner de som eksperimentelle behandlingsformer.

Forfatterne sier meget klart at det i dag ikke er grunnlag for å anbefale populasjonsbasert PSA-screening. Boken etterlater heller ingen tvil om at mange avgjørelser med henblikk på diagnose og behandling av prostatakreft må treffes av mannen selv, i samråd med legen, som bør være informert om de nyeste resultatene av klinisk forskning omkring prostatakreft.

Leserne får også en oversikt over behandling av pasienter med hormonresistent prostatakreft, selv om de nyeste behandlingsmulighetene av kastrasjonsresistent og hormonresistent prostatakreft ikke er omtalt.

I tillegg omtaler forfatterne kort hvordan pasienten selv, etter at diagnosen prostatakreft er stilt, positivt kan påvirke sitt liv ved en helsefremmende livsstil og ved å ha god kontakt med sin fastlege. Spesielt nevneverdig i en slik pasientbrosjyre er omtalen av de forskjellige typene av kliniske forsøk, som et økende antall prostatakreftpasienter kommer til å delta i, i fremtiden.

Målgruppen er altså pasienter med prostatakreft, men boken kan med fordel leses av helsepersonell som skal informere menn før PSA-testing og/eller gi informasjon om moderne behandling av prostatakreft. Den bør også leses av medlemmer i organisasjoner som vurderer å lage en liknende brosjyre for norske menn, f.eks. Kreftforeningen og Prostataforeningen. En norsk oversettelse eller omarbeiding bør også inneholde de to siste årenes erfaringer med moderne andre- og tredjelinjes behandling av prostatakreft. Spesialister i onkologi og urologi vil neppe lære noe nytt av å lese denne boken.

\section{Sophie D. Fosså}

Klinikk for kreft og kirurgi

Oslo universitetssykehus, Rikshospitalet

\section{Solid om flyktninger og asylsøkere}

Dinesh Bhugra, Tom Craig,

Kamaldeep Bhui, red.

Mental health of refugees and asylum seekers

308 s, tab, ill. Oxford: Oxford University Press, 2010. Pris GBP 35

ISBN 978-0-19-955722-6

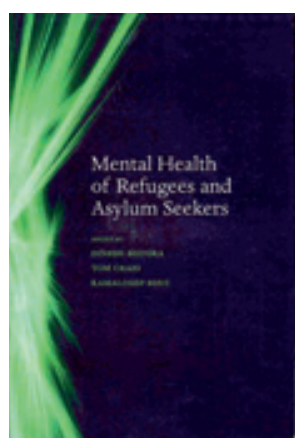

Bidragsyterne gir en relevant og oppdatert innføring i teoretiske og praktiske utfordringer i den psykiske helsetjenesten for flyktninger og asylsøkere. De retter søkelyset mot de spesielle utfordringene ved det å være flyktning, migrasjonens helsebelastninger og hvordan man kan møte pasienter på en best mulig måte. Forfatternes intensjon har vært å løfte et fagfelt uten sterke brukergrupper opp og vise dette som det spennende og interessante fagfeltet det er. Boken retter seg mot terapeuter innen psykisk helse i spesialisthelsetjenesten og helsepersonell i primærhelsetjenesten, men er også relevant for andre som kommer i kontakt med disse gruppene.

Det er 21 kapitler, og bidragsyterne representerer en betydelig kompetanse innen feltet, både fra klinisk praksis og forskning ved universiteter i Europa, USA, Asia og Australia. De presenterer oppdatert og anvendt forskning med kliniske eksempler.

Forfatterne gir en grundig teoretisk innføring, hvor de belyser sammenhengen mellom psykisk helse og migrasjon. De tar opp så vel tilpasning, utfordringer med henblikk på identitet som pre- og postmigrasjonsutfordringer.

Den mer praktisk orienterte delen omhandler psykiatriens kulturelle og språklige utfordringer ved diagnostisering av flyktningpasienter. De belyser terapeutiske forventninger, terapeut-pasient-interaksjon og psykoterapitradisjoner. I møtet mellom ulike kulturelle tradisjoner er det behov for fleksibilitet i behandlerstilen. Etnopsykofarmakologi, etterlevelse, de utfordringene som ligger i ulik sykdomsforståelse og bruk av tradisjonelle preparater behandler de i et eget kapittel.

I den siste delen tar forfatterne for seg mer spesielle fagfelt innen psykisk helse, som selvmord blant flyktninger, følger av seksuelle overgrep, barn som flyktninger, og flyktningfamiliers spesielle behov. Posttraumatisk stresslidelse omtaler de med henvisning til forskning og klinisk praksis. Nevrobiologisk forskning har bidratt til et nytt perspektiv på behandling av traumatisk stress og lidelser som stresset kan føre til. Dette er illustrert med eksempler fra anbefalte terapeutiske tilnærminger, som blant annet traumefokusert kognitiv terapi (T-CBT) og EMDR (eye movement desensitizing and reprocessing).

Norge har fått en flerkulturell hverdag som helsepersonell på alle nivåer må forholde seg til, og det er underforbruk av psykiske helsetjenester blant flyktninger og asylsøkere. Forskning også her i landet viser at det er en tett sammenheng mellom migrasjonsutfordringer, sosioøkonomiske forhold og psykisk uhelse i innvandrerbefolkningen. I liten grad har vi tatt de involverte pasientgruppene med på råd eller sett på tradisjonelle mestringsstrategier fra deres opprinnelseskultur.

Denne boken er et viktig bidrag til et fagfelt som trenger mer oppmerksomhet i Helse-Norge. Det vestlige perspektivet og de terapitradisjonene som er rådende, får her en faglig velfundert utfordring. Boken gir et solid inntrykk og er godt underbygd med oppdatert forskning fra sentrale og relevante kilder.

\section{Birgit Lie}

Poliklinikk for psykosomatikk og traumer Sørlandet sykehus 